\title{
Analisis Perbandingan Penalaran Kreatif Soal Ujian Nasional Matematika Tahun 2016 Tingkat Sekolah Lanjutan Atas
}

\author{
R. Haqi ${ }^{1)}$, W. Susilawati ${ }^{1 *}$, dan Juariah ${ }^{1)}$ \\ 1) Prodi Pendidikan Matematika, UIN Sunan Gunung Djati Bandung, \\ Jl. A.H. Nasution No. 105, Bandung 40614, Indonesia \\ *Email: wati85@uinsgd.ac.id
}

Dikirim: 10 Agustus 2017 ; Diterima: 08 November 2017; Dipublikasikan: 20 Desember 2017

\begin{abstract}
Abstrak. Penelitian ini merupakan penelitian deskriptif kualitatif yang bertujuan untuk mengetahui kandungan penalaran kreatif berdasarkan kerangka kerja penalaran Johan Lithner dalam soal Ujian Nasional Matematika SMA/MA jurusan MIPA Tahun Ajaran 2015/2016, implementasinya terhadap siswa kelas 11 MIPA MAN 2 Bandung dan SMAN 26 Bandung, serta kendala dan hambatan guru dan siswa dalam menghadapi soal penalaran kreatif. Data yang diperoleh berasal dari instrumen tes dan nontes. Berdasarkan hasil penelitian diperoleh: (a) Soal Ujian Nasional Matematika SMA/MA jurusan MIPA Tahun Ajaran 2015/2016 mengandung sebagian kecil soal penalaran kreatif; (b) Kemampuan penalaran kreatif siswa kelas 11 MIPA MAN 2 Bandung dan SMAN 26 Bandung masih kurang; (c) Kendala utama guru dalam memberikan pembelajaran dengan menggunakan soal penalaran kreatif adalah kurangnya waktu untuk memenuhi materi yang harus dikuasai siswa; (d) Kendala utama siswa dalam mengerjakan soal penalaran kreatif adalah kurangnya kepercayaan diri mereka dalam mengerjakan soal.
\end{abstract}

Kata Kunci. Penalaran Kreatif, Ujian Nasional

\section{Pendahuluan}

Berdasarkan Standar Isi BSNP tentang Standar Kompetensi dan Kompetensi Dasar tahun 2006 (BSNP, 2006: 146), penalaran merupakan salah satu kompetensi yang harus dicapai siswa dalam pembelajaran matematika. Keraf (1982: 5) menjelaskan bahwa penalaran atau jalan pikir atau reasoning adalah proses bepikir yang berusaha menghubung-hubungkan faktafakta atau evidensi-evidensi yang diketahui menuju kepada suatu kesimpulan. Kebanyakan siswa SMA/MA di Bandung masih kesulitan dalam mengerjakan soal penalaran. Rata-rata persentase kesulitan yang dialami oleh siswa SMA/MA di Bandung dalam mengerjakan soal penalaran adalah 63,25\% (Sulistiawati, 224: 
2014). Begitu juga dengan guru di sekolah, mereka masih merasa kesulitan dalam memberikan pengajaran kepada siswa dengan menggunakan soal penalaran (Ikram, 56: 2016).

Kemampuan penalaran yang masih rendah juga terdapat pada daya nalar siswa di MAN 2 Bandung dan SMAN 26 Bandung, hal ini dibuktikan dengan masih kecilnya passing grade yang berlaku di MAN 2 Bandung dan SMAN 26 Bandung pada masa PPDB tahun 2016 jika dibandingkan dengan sekolah negeri lain yang ada di Kota Bandung, yaitu 291 untuk SMAN 26 Bandung dan 306 untuk MAN 2 Bandung (Fauzan, 2016). Mengingat ada 3 kompetensi matematika yang harus dipenuhi oleh siswa dalam Ujian Nasional, salah satunya adalah penalaran, maka kemampuan penalaran di MAN 2 Bandung dan SMAN 26 Bandung masih rendah.

Ujian Nasional merupakan salah satu standar kelulusan bagi siswa yang duduk di bangku sekolah, dimana tes tersebut dilakukan secara nasional pada jenjang pendidikan menengah. Kenyataan menunjukkan bahwa pada mata pelajaran matematika hasil belajar yang ditunjukkan siswa Indonesia belum memuaskan. Rendahnya hasil belajar matematika semakin terlihat jelas ketika mencermati hasil yang diperoleh siswa dalam Ujian
Nasional. Jika ditinjau lebih lanjut maka dapat disimpulkan bahwa yang menjadi masalah bukanlah pada Ujian Nasional yang diselenggarakan oleh pemerintah, melainkan kurang mampunya siswa memahami ataupun mengenali struktur dan komposisi soal Ujian Nasional yang berimbas pada kurang mampunya siswa menyelesaikan soal-soal tersebut (Kolopita, 2015: 2).

Penelitian empiris yang dilakukan oleh Lithner (2006) telah ditemukan dan didefinisikan dua tipe penalaran matematika, yaitu creative mathematically founded reasoning (penalaran kreatif matematis) dan imitative reasoning (penalaran tiruan). Creative mathematically founded reasoning (penalaran kreatif matematis) adalah sebuah kerangka kerja yang dipandang sebagai sebuah hasil dari berfikir matematika kreatif.

Pada Ujian Nasional tahun 2016 soal akan dibagi ke dalam 3 level kognitif, yaitu pengetahuan dan pemahaman, aplikasi, dan penalaran. Menurut Suprananto (2016) soal penalaran merupakan soal dengan kategori High Order Thinking Skill atau kemampuan berpikir tingkat tinggi, sehingga memaksa siswa untuk berpikir dengan cara yang tidak sederhana. Begitu juga dengan penalaran kreatif yang akan dibahas dalam penelitian ini. Penalaran kreatif atau Creative 
Reasoning (CR) terbagi dalam dua kelompok besar, yakni Local Creative Reasoning (LCR) dan Global Creative Reasoning (GCR).

Dengan melihat pada kenyataan bahwa hasil Ujian Nasional Matematika 2016 yang juga masih rendah dan pada penelitian sebelumnya telah ditemukan bahwa soal bertipe IR lebih mendominasi dibandingkan dengan soal bertipe CR. Paradigmaparadigma seperti ini perlu dihindari. Guruguru di Indonesia perlu mengajarkan soalsoal yang menuntut siswa untuk bernalar secara kreatif agar kualitas matematis siswa meningkat.

Kualitas pembelajaran matematika di Jawa Barat masih cukup rendah. Hal tersebut terjadi karena kualitas guru matematika di Jawa Barat rendah. Hal tersebut berdampak pada kualitas pembelajaran matematika siswa, dan kemudian berdampak pada hasil Ujian Nasional mata pelajaran Matematika di Jawa Barat.

Tujuan diadakannya penelitian ini adalah untuk mengetahui seberapa besar kandungan soal penalaran kreatif menurut kerangka kerja Lithner dalam soal Ujian Nasional Matematika jurusan MIPA tahun pelajaran 2015/2016 tingkat SMA/MA dan implementasinya terhadap siswa serta kendala dan hambatan guru dan siswa dalam menghadapi soal penalaran kreatif.

\section{Metodologi Penelitian}

Metode yang digunakan dalam penilitian ini adalah metode penelitian deskriptif. Jenis penelitian deskriptif yang di gunakan pada penelitian ini adalah studi kecenderungan. Studi kecenderungan pada dasarnya meramalkan keadaan masa depan bedasarkan keadaan, gejala, data yang ada pada masa sekarang (Arifin, 2011: 54).

Jenis data yang dikumpulkan dalam penelitian ini adalah data kualitatif berupa naskah soal Ujian Nasional Matematika tingkat SMA Jurusan MIPA tahun pelajaran 2015/2016, lembar analisis terhadap naskah soal tersebut, lembar kuesioner yang berisi tentang kendala dan hambatan guru dalam memberikan pembelajaran soal yang mengandung penalaran kreatif dan kendala dan hambatan siswa dalam mengerjakan soal yang mengandung penalaran kreatif dan data kuantitatif berupa hasil tes soal Ujian Nasional Matematika jurusan MIPA tahun ajaran 2015/2016 yang mengandung penalaran kreatif.

Instrumen penelitian yang digunakan dalam penelitian ini adalah (1) Soal Ujian Nasional, Soal Ujian Nasional yang 
diberikan kepada siswa MAN 2 Bandung dan SMAN 26 Bandung yang digunakan sebagai tes adalah soal Ujian Nasional yang mengandung penalaran kreatif berdasarkan kerangka kerja Lithner yang telah dianalisis oleh penganalisis soal dan memuat materi kelas 10 dan kelas 11 dalam Kurikulum 2013 yang dibentuk ke dalam soal essay; (2) Lembar Analisis, lembar analisis dalam penelitian ini berupa rubrik penilaian soal Ujian Nasional yang digunakan untuk mengetahui kandungan penalaran kreatif dalam soal Ujian Nasional Matematika SMA/MA tahun 2016 jurusan MIPA.

Rubrik penilaian soal Ujian Nasional adalah instrumen yang digunakan untuk menganalisis kandungan penalaran kreatif dalam soal Ujian Nasional. Rubrik penilaian soal kategori LCR dan GCR dapat memudahkan peneliti dalam pengambilan kesimpulan kandungan penalaran kreatif dalam soal Ujian Nasional; (3) Lembar Kuesioner, lembar kuesioner dalam penelitian ini berupa angket terbuka yang akan diberikan kepada guru matematika dan siswa kelas 11 MIPA di MAN 2 Bandung dan SMAN 26 Bandung terkait dengan kendala dan hambatan mereka dalam menghadapi soal yang mengandung penalaran kreatif.
Data yang akan digunakan pada penelitian ini akan dianalisis terlebih dahulu, dengan prosedur-prosedur di bawah ini:

a. analisis kandungan penalaran kreatif

Untuk menganalisis data mengenai jenis penalaran kreatif dapat dilakukan 4 langkah analisis berikut:

Langkah 1: Analisis soal Ujian Nasional Langkah 2: Analisis penciri LCR dan GCR

Langkah 3: Argumentasi dan kesimpulan Langkah 4: Analisis kuantitatif

b. analisis hasil implementasi soal penalaran kreatif

Untuk menganalisis hasil implementasi soal penalaran kreatif pada soal Ujian Nasional Matematika dilakukan dengan cara membandingkan nilai rata-rata hasil tes soal Ujian Nasional di MAN 2 Bandung dan SMAN 26 Bandung, lalu dianalisis secara deskriptif.

c. analisis kuesioner

Untuk menganalisis kuesioner yang diberikan kepada siswa dan guru dilakukan dengan cara analisis secara deskriptif.

\section{Hasil dan Pembahasan}

a. Jenis Penalaran Kreatif Berdasarkan Kerangka Kerja Lithner

Setelah dilakukan penelitian pada soal UN Matematika SMA/MA Jurusan MIPA tahun pelajaran 2015/2016 Paket UAC1102, 
UAC2202, dan UAC5502 diperoleh hasil bahwa ternyata soal UN memiliki jenis soal yang sama dalam setiap paketnya, hanya berbeda dalam penyajian angka dan redaksi katanya saja. Hal ini mempengaruhi kandungan penalaran kreatif yang terdapat pada soal UN Matematika SMA/MA Jurusan MIPA tahun pelajaran 2015/2016 Paket UAC1102, UAC2202, dan UAC5502.

Setiap paket soal memiliki persentase kandungan penalaran yang sama. Pada paket UAC1102 terdapat 12 soal yang termasuk ke dalam tipe soal LCR dan 4 soal yang termasuk ke dalam tipe soal GCR, dengan demikian terdapat $40 \%$ dari 40 soal UN yang berjenis soal penalaran kreatif. Pada paket UAC2202 terdapat 12 soal yang termasuk ke dalam tipe soal LCR dan 4 soal yang termasuk ke dalam tipe soal GCR, dengan demikian terdapat $40 \%$ dari 40 soal UN yang berjenis soal penalaran kreatif. Pada paket UAC5502 terdapat 11 soal yang termasuk ke dalam tipe soal LCR dan 5 soal yang termasuk ke dalam tipe soal GCR, dengan demikian terdapat $40 \%$ dari 40 soal UN yang berjenis soal penalaran kreatif.

Dalam penelitian ini ditemukan bahwa kadar soal penalaran kreatif dari setiap paket soal memiliki kadar persentase yang sama, yaitu $40 \%$ atau 16 soal dalam setiap paketnya. Mengingat soal bertipe penalaran kreatif termasuk ke dalam soal dengan kategori sedang dan sulit, maka hal ini sesuai dengan apa yang dikatakan oleh Nizam (2016) bahwasanya soal tingkat kesulitan soal UN 2016 akan sama dengan soal UN tahun sebelumnya, yaitu $20 \%$ soal dengan kategori sulit, $70 \%$ persen sedang, dan $10 \%$ persen mudah, dengan $60 \%$ soal lainnya merupakan soal berkategori imitative reasoning yang termasuk ke dalam tingkat kesulitan mudah dan sedang. b. Implementasi Penalaran Kreatif Berdasarkan Kerangka Kerja Lithner pada Soal Ujian Nasional Matematika Jurusan MIPA Tingkat Sekolah Lanjutan Atas Tahun Pelajaran 2015/2016 di MAN 2 Bandung dan SMAN 26 Bandung

Dari hasil analisis soal berdasarkan kerangka kerja penalaran Lithner yang telah dilakukan oleh 4 orang penganalisis, didapatkan 16 soal pada paket UAC1102, 16 soal pada paket UAC2202, dan 16 soal pada paket UAC550 yang mengandung penalaran kreatif menurut kerangka kerja Lithner. Namun karena peneliti akan mengimplementasikan soal tersebut kepada siswa kelas 11 MIPA, maka peneliti merangkum kembali soal-soal tersebut ke dalam materi yang telah mereka pelajari di kelas 10 dan kelas 11, setelah dikonsultasikan kepada guru matematika 
MAN 2 Bandung dan SMAN 26 Bandung akhirnya didapatkan 5 soal dari masingmasing paket soal UAC1102, UAC2202, dan UAC5502 yang diberikan kepada 35 siswa kelas XI MIPA 1 MAN 2 Bandung dan 29 siswa kelas XI MIPA 6 SMAN 26 Bandung.

Tabel 1. Soal Tes Penalaran Kreatif

\begin{tabular}{|c|c|c|c|}
\hline No & Paket Soal & Nomor Soal & Materi \\
\hline 1 & UAC1102 & $4,8,12,17,40$ & \multirow{3}{*}{$\begin{array}{c}\text { Fungsi Logaritma, Persamaan } \\
\text { Kuadrat, SPLDV, Program } \\
\text { Linear, Polinomial, Barisan dan } \\
\text { Deret Geometri, Aturan } \\
\text { Pencacahan }\end{array}$} \\
\hline 2 & UAC2202 & $3,8,12,17,40$ & \\
\hline 3 & UAC5502 & $6,7,12,17,40$ & \\
\hline
\end{tabular}

Setelah dilakukan pemberian soal kepada siswa MAN 2 Bandung dan SMAN 26 Bandung, soal dianalisis berdasarkan indikator jawaban soal penalaran yang terdapat pada sub bab teknik analisis data dan dinilai dengan skala penilaian 0-100. Berikut hasil ringkasan penilaian penalaran kreatif siswa di MAN 2 Bandung dan SMAN 26 Bandung dan hasil rinci penilaian masing-masing siswa akan dilampirkan.

Tabel 2. Hasil Skor Penalaran Siswa di MAN 2 Bandung dan SMAN 26 Bandung

\begin{tabular}{|c|c|c|c|c|c|c|c|c|c|}
\hline \multirow{2}{*}{ Nama Sekolah } & \multicolumn{5}{|c|}{ Jumlah Skor per Nomor } & \multirow{2}{*}{$\begin{array}{c}\text { Nilai } \\
\text { Tertinggi } \\
\end{array}$} & \multirow{2}{*}{\begin{tabular}{|c|c} 
Nilai \\
Terendah \\
\end{tabular}} & \multirow{2}{*}{$\begin{array}{c}\text { Rata-Rata } \\
\text { Nillai }\end{array}$} & \multirow{2}{*}{$\begin{array}{l}\text { Standar } \\
\text { Deviasi } \\
\end{array}$} \\
\hline & 1 & 2 & 3 & 4 & 5 & & & & \\
\hline MAN 2 Bandung & 16 & 49 & 23 & 32 & 32 & 95 & 0 & 21,71 & 24,28 \\
\hline SMAN 26 Bandung & 31 & 97 & 8 & 78 & 44 & 80 & 20 & 46,38 & 15,29 \\
\hline
\end{tabular}

Setelah melakukan penelitian bagaimana tingkat kemampuan penalaran kreatif pada siswa MAN 2 Bandung dan SMAN 26 Bandung, peneliti menemukan adanya perbedaan tingkat kemampuan penalaran kreatif antara siswa MAN 2 Bandung dan SMAN 26 Bandung.

Dari hasil tes dapat dilihat bahwa nilai ratarata SMAN 26 Bandung lebih baik dibandingkan dengan nilai rata-rata MAN 2 Bandung, begitu juga dengan nilai simpangan baku, penyebaran nilai tes di SMAN 26 Bandung lebih merata dibandingkan dengan nilai tes di MAN 2 Bandung. Namun, jika dianalisis satu per satu hasil jawaban siswa di SMAN 26 Bandung ditemukan letak kesalahan yang dilakukan oleh setiap siswa dengan paket soal yang sama hampir serupa, sehingga hal ini tentu menyebabkan penyebaran nilai tes yang merata. Salah satu faktor yang memicu terjadinya hal tersebut adalah pemikiran setiap siswa yang sama dalam mengerjakan soal, sehingga mereka selalu memakai cara yang sama ketika mengerjaka soal yang diberikan.

c. Kendala dan Hambatan Guru Matematika MAN 2 Bandung dan SMAN 26 Bandung dalam Memberikan Pembelajaran dengan Soal yang Mengandung Penalaran Kreatif

Hampir setiap guru matematika di MAN 2 Bandung dan SMAN 26 Bandung memiliki kendala dan hambatan yang sama dalam memberikan pembelajaran dengan soal penalaran yang mengandung penalaran 
kreatif, yaitu kurangnya waktu yang dimiliki oleh guru ketika memberikan siswa pembelajaran dengan menggunakan penalaran kreatif. Farista (2013) mengemukakan bahwa setiap cabang matematika satu dengan yang lainnya saling berhubungan, sehingga butuh cukup banyak waktu agar seluruh materi guna mengembangkan daya nalar siswa dapat terpenuhi. Namun setiap guru selalu mencoba untuk meningkatkan daya nalar siswa dengan selalu memberikan soal yang baru dengan tingkat kesulitan yang bertahap dan memberikan siswa soal yang memiliki banyak solusi sehingga memicu siswa untuk berpikir kreatif.

d. Kendala dan Hambatan Siswa MAN 2 Bandung dan SMAN 26 Bandung dalam Mengerjakan Soal yang Mengandung Penalaran Kreatif

Dari hasil tes yang diberikan kepada siswa MAN 2 Bandung dan SMAN 26 Bandung, dapat dilihat bahwa kemampuan penalaran kreatif siswa di kedua sekolah tersebut masih kurang dan masih memiliki beberapa kendala dalam pengerjaan soal. Dari hasil penelitian, didapatkan beberapa kendala siswa dalam mengerjakan soal penalaran kreatif, yaitu siswa tidak memahami sifatsifat awal logaritma, siswa tidak mampu menginprentasikan pertidaksamaan fungsi aljabar ke dalam bentuk garis bilangan, kesalahan dalam pengambilan kesimpulan, siswa tidak mampu mengubah soal cerita ke dalam model matematika, siswa tidak memahami materi soal dengan baik, siswa tidak memahami materi soal dengan baik, kesalahan dalam pengambilan strategi, dan kehabisan waktu.

Hal itu bertolak belakang dengan apa yang mereka utarakan ketika menjawab kuesioner. Kebanyakan dari mereka pernah bahkan sering mengerjakan soal yang baru dan memiliki banyak solusi, yang artinya mereka telah terbiasa mengerjakan soal bertipe penalaran kreatif. Hal ini yang menjadi tanda tanya, mengapa mereka tidak dapat mengerjakan soal yang diberikan dengan baik, sedangkan mereka telah terbiasa mengerjakan soal dengan jenis yang sama. Ternyata pertanyaan tersebut dapat terjawab oleh jawaban dari pertanyaan nomor 5 dan 7 pada kuesioner, yaitu "Ungkapkan kendala dan hambatan Anda dalam mengerjakan soal yang solusi jawabannya berbeda dengan apa yang diajarkan oleh guru dan membutuhkan modifikasi rumus untuk menjawabnya!” dan "Ungkapkan kendala dan hambatan Anda dalam mengerjakan soal yang solusi jawabannya bisa menggunakan beberapa cara!", banyak siswa yang mengatakan bahwa kendala mereka adalah karena tidak yakinnya mereka tehadap cara yang mereka 
kerjakan jika cara tersebut berbeda dengan apa yang guru mereka ajarkan, bahkan ada beberapa siswa yang mengatakan bahwa mereka takut jawaban mereka disalahkan oleh guru jika solusi jawaban mereka berbeda dengan yang lainnya, sehingga mereka menjadi kurang percaya diri dengan apa yang mereka telah kerjakan sendiri.

Salah satu faktor yang mempengaruhi hasil belajar adalah kepercayaan diri (Martyanti, 17: 2013). Hannula, Maijala, dan Pehokonen (Martyanti, 17: 2013) mengungkapkan bahwa kepercayaan (belief) terhadap diri sendiri memiliki hal yang luar biasa dengan kesuksesan siswa dalam belajar matematika. Hal itu yang menyebabkan mereka harus menghapal dan mengingat tahap demi tahap, langkah demi langkah solusi jawaban yang guru mereka ajarkan, hal demikian yang membuat mereka cepat lupa rumus matematika, karena pada dasarnya matematika itu untuk dimengerti, bukan hanya untuk diingat.

\section{Simpulan dan Saran}

\section{a. Simpulan}

Berdasarkan hasil penelitian maka dapat disimpulkan:

1) Jenis penalaran kreatif berdasarkan kerangka kerja Lithner yang digunakan siswa dalam Ujian Nasional Matematika jurusan MIPA tingkat Sekolah Lanjutan
Atas tahun pelajaran 2015/2016 adalah mengandung sebagian kecil penalaran kreatif bertipe LCR dan GCR.

2) Berdasarkan hasil implementasi penalaran kreatif berdasarkan kerangka kerja Lithner dalam soal-soal Ujian Nasional Matematika jurusan MIPA di MAN 2 Bandung dan SMAN 26 Bandung tahun pelajaran 2015/2016 ditemukan bahwa kemampuan siswa dalam mengerjakan soal yang berjenis penalaran kreatif di SMAN 26 Bandung dan MAN 2 Bandung masih kurang.

3) Kendala dan hambatan guru pada saat memberikan pembelajaran dengan menggunakan soal penalaran kreatif adalah kurangnya waktu yang dimiliki oleh gruru untuk memberika pebelajaran dengan soal penalaran kreatif kepada siswa.

4) Kendala dan hambatan utama siswa dalam mengerjakan soal yang berjenis penalaran kreatif adalah kurangnya kepercayaan diri siswa dalam mengerjakan soal penalaran kreatif.

\section{b. Saran}

Saran-saran yang dapat diberikan oleh peneliti setelah dilakukannya penelitian ini adalah sebagai berikut:

1) Bagi peneliti selanjutnya, dianjurkan ketika sedang melakukan penelitian pengawasan harus lebih ketat agar siswa 
lebih disiplin dan tidak terjadi suatu hal yang tidak diinginkan.

2) Agar siswa menjadi lebih percaya diri dan termotivasi dalam menghadapi pembelajaran matematika, dapat digunakan strategi pembelajaran yang dapat memicu rasa percaya diri siswa.

3) Strategi pembelajaran yang dapat dilakukan oleh guru guna mempersiapkan siswanya menghadapi Ujian Nasional selanjutnya adalah dengan memberikan soal-soal bertipe penalaran kreatif agar siswa dapat terbaisa dengan soal-soal bertipe demikian.

\section{Daftar Pustaka}

BSNP. (2006). Standar isi untuk satuan pendidikan dasar dan menengah: standar kompetensi dan kompetensi dasar SMA/MA. Jakarta.

Farista, M. Irsadi. (2013). Ilmu dan matematika. [online]. Tersedia: https://irsadifarista.wordpress.com/fil safat/ilmu-dan-matematika/ $\quad[8$ Agustus 2017]

Fauzan. (2016). Passing grade SMA di PPDB kota Bandung 2016 [online]. Tersedia:

http://www.fauzanalfi.com/2016/07/ passing-grade-sma-di-ppdb-kotabandung-2016/ [8 Agustus 2017]

Keraf, G. (1982). Argumen dan narasi. Komposisi Lanjutan III. Jakarta: Gramedia.
Kolopita, Triyawan. (2015). Analisis struktur dan kemampuan siswa dalam menyelesaikan soal Ujian Nasional Matematika SMP/MTs tahun 2013/2014 menggunakan kerangka kerja Lithner. Universitas Negeri Gorontalo.

Lithner, J. (2006). A research framework for creative and imitative reasoning". Journal Educational Studies in Mathematics, Vol.67, No.3, pp.255276.

Martyanti, Adhetia. (2013). Membangun self-confidance siswa dalam pembelajaran matematika dengan pendekatan problem solving. Universitas Negeri Yogyakarta. ISBN : 978-979-16353-9-4

Ikram, Muhammad. (2016). Analysis of mathematics teacher problem in learning implementation senior high school. Cokroaminoto Palopo University, Vol. 1, No.1, ISSN : 2502 -3802 .

Sulistiawati. (2014). Analisis kesullitan belajar kemampuan penalaran matematis siswa SMP pada materi luas permukaan dan volume limas. STKIP Surya. ISBN : 978 $-602-14432-2-4$

Arifin, Zainal. (2012). Penelitian Pendidikn: Metode dan Paradigma Baru. Bandung: Rosdakarya. 